Article

\title{
Levels of Antioxidant Compound Glutathione in Moss from Industrial Areas
}

\author{
Zulema Varela ${ }^{1, *(1)}$, Sofía Debén ${ }^{1}$, Dinesh K. Saxena ${ }^{2}$, Jesús R. Aboal ${ }^{1}$ and \\ J. Ángel Fernández 1 (it)
}

1 Ecology Unit, Department of Functional Biology, Universidade de Santiago de Compostela, Fac. Bioloxía, Lope Gómez de Marzoa s/n, Santiago de Compostela, 15702 A Coruña, Spain; debensofia@gmail.com (S.D.); bfjaboal@usc.es (J.R.A.) jangel.fernandez@usc.es (J.Á.F.)

2 Department of Botany, Bareilly College, Bareilly, U.P. 243001, India; dinesh.botany@gmail.com

* Correspondence: zulema.varela@usc.es or zvarelario@gmail.com; Tel.: +34-881-81-33-14

Received: 11 May 2018; Accepted: 18 July 2018; Published: 19 July 2018

\begin{abstract}
Plants possess a wide range of cellular mechanisms that help them tolerate potentially toxic substances. Several studies that were carried out under laboratory conditions have demonstrated that the antioxidant compound glutathione plays a role in enabling mosses to tolerate high levels of heavy metals without toxic effects. However, until now, the antioxidant levels have not been studied in mosses under field conditions. In this study, we aimed to clarify the antioxidant concentrations of glutathione in the terrestrial moss Pseudoscleropodium purum growing in industrial environments characterised by high atmospheric levels of $\mathrm{Cd}, \mathrm{Ni}$, and $\mathrm{Pb}$, and to evaluate the potential use of the compound as a biomarker. The results indicated the existence of a glutathione threshold response, which was significantly correlated with the metal toxicity and which may be influenced by metal bioavailability. Although future studies are needed to strengthen the findings, the present study suggests that total concentration of glutathione in P. purum could therefore be used as a biomarker in air pollution biomonitoring studies, provided that metal bioavailability is taken into account.
\end{abstract}

Keywords: biomarkers; heavy metals; glutathione; Pseudocleropodium purum; tolerance

\section{Introduction}

Monitoring air quality is currently one of the main objectives of governments worldwide because of the high degree of industrialization that has taken place in the last century. Organisms such as bryophytes (mainly terrestrial mosses) have been widely used to biomonitor various different atmospheric pollutants [1,2]. However, scientific evidence supporting the use of bryophytes as biomonitors is only available for some heavy metals, such as $\mathrm{Pb}$ and $\mathrm{Cd}[3,4]$. The high cation exchange capacity of moss cells [5-7] and the high capacity of the cells to retain particles [8,9] allow mosses to bioconcentrate high levels of pollutants in their tissues. However, the physiological responses that allow moss cells to tolerate high levels of pollution without suffering toxic effects have not been studied in detail until now. In addition, although relevant studies have been conducted under laboratory conditions [10-12], no such studies have been carried out under field conditions.

The presence of heavy metals in the tissues of algae, fungi, and higher plants generates an oxidative stress that activates multiple response mechanisms that help to protect cells from damage [13-15]. The mechanism that is most commonly activated in response to this type of environmental stress is the synthesis of antioxidants, and glutathione is a key part of this antioxidant network that plays a crucial role in the maintenance of cellular redox homeostasis [16-20]. Glutathione, an intracellular tripeptide thiol that is composed of glutamic acid, cysteine, and glycine, has important functions in the regulation of biotic stress reactions, as well as in cellular metabolism and redox signalling [19]. When higher plants 
are exposed to high levels of heavy metals, glutathione induces the synthesis of phytochelatins (PCs), peptides whose function is to chelate metals that are present in the cytosol of the cells, thus decreasing the potential toxicity of the metals and enabling plants to tolerate them $[10,18,20]$. Although different authors have questioned the role of PCs in the development of heavy metal tolerance due to the energy costs that are associated with sulphate reduction and PC synthesis [21,22], in many cases under stress conditions, plant cells contain a high concentration of PCs and a low concentration of glutathione [23,24]. Nevertheless, unlike in higher plants, the synthesis of PCs has not been observed for most bryophytes in response to high levels of heavy metals $[10,23,25,26]$. Researchers investigating the glutathione response in terrestrial and aquatic mosses have observed increased glutathione concentrations, however not PC concentrations, in mosses that have been exposed to high concentrations of $\mathrm{Cd}, \mathrm{Ni}$, and $\mathrm{Pb}[10-12,25,27]$. Only Petraglia et al. [28] showed the presence of PC in the moss Sphagnum palustre and in several liverworts that were exposed to $\mathrm{Cd}$. These findings suggest that a specific biochemical response occurs in bryophytes, and that metals may be chelated by glutathione during their transport through the cytoplasm, as suggested by Bruns et al. [10].

It is possible that in the presence of high levels of heavy metals in the cellular cytoplasm, glutathione begins to chelate the metals and transform them into new, less toxic compounds with different chemical properties, thus preventing damage to cells. This antioxidant compound would therefore allow mosses to tolerate the presence of metallic pollutants. In relation to biomonitoring with terrestrial mosses, it would be useful to determine whether the glutathione response actually exists, as the presence of this compound could be used as a biomarker. However, until now, the antioxidant response has not been studied in mosses under field conditions. Therefore, the main objectives of the present study were to clarify the antioxidant concentrations of glutathione in the terrestrial moss Pseudoscleropodium purum in industrial environments characterized by high atmospheric levels of $\mathrm{Cd}$, $\mathrm{Ni}$, and $\mathrm{Pb}$, and to evaluate the potential use of the compound as a biomarker.

\section{Material and Methods}

\subsection{Sampling and Processing}

Samples of the terrestrial moss Pseudoscleropodium purum (Hedw.) M. Fleisch. were collected in February 2015 from the surroundings of five factories in Galicia (NW Spain) that were known to emit different heavy metals [1,29]: two ferrous smelters (A and B), an aluminium smelter (C), a ceramics factory (D), and a chipboard manufacturing plant (E). Using the focal point of emission of the pollutants as the starting point, a transect was established in the surroundings of each factory, with 2 or 3 sampling sites (SS) located at increasing distances along each transect (Table 1). Approximately 30 subsamples were collected at each SS and were combined to form a single composite sample [30]. Whenever possible, the size of the sampling area was between $30 \times 30$ and $50 \times 50 \mathrm{~m}$. The samples of moss were transported to the laboratory where they were cleaned to remove plant remains and adhering material, before apical segments were separated from the shoots [2]. The apical segments (ca. $0.3 \mathrm{~g}$ f.w.) were then homogenized in liquid nitrogen with the aid of a hammer drill (Nupower Evolution) and were stored in a freezer (Revco ${ }^{\circledR}$ Elite plus, Thermo Scientific, Asheville, NC, USA) at $-80^{\circ} \mathrm{C}$ before analysis to prevent the degradation of the glutathione content. Other apical segments were separated and were stored for later chemical analysis. 
Table 1. Description of sampling sites (SS): coordinates and distance from the factories.

\begin{tabular}{|c|c|c|c|c|c|c|c|}
\hline \multirow{2}{*}{ ID } & \multirow{2}{*}{ Factories } & \multicolumn{2}{|c|}{ UTM } & \multirow{2}{*}{ SS } & \multicolumn{2}{|c|}{ UTM } & \multirow{2}{*}{$\begin{array}{l}\text { Distance } \\
\text { (Meters) }\end{array}$} \\
\hline & & $X$ & Y & & $X$ & $\mathbf{Y}$ & \\
\hline \multirow{3}{*}{ A } & \multirow{3}{*}{ Ferrous smelter } & \multirow{3}{*}{567779} & \multirow{3}{*}{4818462} & A1 & 567549 & 4818831 & 433 \\
\hline & & & & $\mathrm{A} 2$ & 567691 & 4819795 & 1300 \\
\hline & & & & A3 & 568190 & 4819634 & 1200 \\
\hline \multirow{2}{*}{ B } & \multirow{2}{*}{ Ferrous smelter } & \multirow{2}{*}{485739} & \multirow{2}{*}{4755025} & B1 & 486111 & 4755275 & 447 \\
\hline & & & & B2 & 487005 & 4755784 & 1500 \\
\hline \multirow{3}{*}{$\mathrm{C}$} & \multirow{3}{*}{ Aluminium smelter } & \multirow{3}{*}{623612} & \multirow{3}{*}{4839748} & $\mathrm{C} 1$ & 623018 & 4839320 & 734 \\
\hline & & & & $\mathrm{C} 2$ & 622255 & 4839947 & 1400 \\
\hline & & & & $\mathrm{C} 3$ & 622030 & 4838827 & 1800 \\
\hline \multirow{2}{*}{$\mathrm{D}$} & \multirow{2}{*}{ Ceramic factory } & \multirow{2}{*}{544900} & \multirow{2}{*}{4659827} & D1 & 545087 & 4659794 & 200 \\
\hline & & & & D2 & 545288 & 4660846 & 1100 \\
\hline \multirow{2}{*}{ E } & \multirow{2}{*}{ Chipboard manufacturing } & \multirow{2}{*}{575695} & \multirow{2}{*}{4819339} & E1 & 575568 & 4819649 & 339 \\
\hline & & & & E2 & 576410 & 4819930 & 930 \\
\hline
\end{tabular}

\subsection{Determination of Glutathione Levels}

The frozen moss samples were centrifuged at $12,000 \mathrm{rpm}$ for $15 \mathrm{~min}$ at $4{ }^{\circ} \mathrm{C}$, and the supernatants of each sample were collected for analysis. To determine the total glutathione concentrations in the samples, we used the "OxiSelect ${ }^{\mathrm{TM}}$ Total Glutathione (GSSG/GSH) Assay Kit (Cell Biolabs Inc., San Diego, CA, USA)". The assay principle is based on the activity of glutathione reductase, which reduces oxidized glutathione (GSSG) to reduced glutathione (GSH) in the presence of NADPH. A chromogen then reacts with the thiol group of GSH to produce a coloured compound with a maximum absorption at $405 \mathrm{~nm}$. The total glutathione concentrations in the samples ( $\mu \mathrm{g} \mathrm{g}^{-1}$ f.w.) were determined using a previously constructed glutathione standard curve (ranging between 0 and $0.5 \mu \mathrm{M})$. The rate of chromophore production is proportional to the concentration of glutathione in the sample, and it can be determined from the change in absorbance over time.

The absorbance values were measured in a microplate reader (Beckman Coulter DTX 880 multimode detector, Beckman Coulter, Brea, CA, USA). Aliquots $(100 \mu \mathrm{L})$ of the sample to be analysed, or prepared glutathione standards, plus $25 \mu \mathrm{L}$ of glutathione reductase, $25 \mu \mathrm{L}$ of NADPH, and finally, $50 \mu \mathrm{L}$ of chromogen were added to the wells of a microplate. Immediately after the addition of the chromogen, the absorbance (at $405 \mathrm{~nm}$ ) was measured at 1-minute intervals for 10 minutes. Each sample was processed twice, and the samples were reanalysed when the corresponding standard deviations were higher than $10 \%$.

\subsection{Chemical Analysis}

The moss samples (ca. $0.3 \mathrm{~g}$ d.w.) were digested in $1 \mathrm{~mL}$ of $\mathrm{H}_{2} \mathrm{O}_{2}(30 \%)$ and $5 \mathrm{~mL}$ of aqua regia $\left(1 \mathrm{HNO}_{3}: 3 \mathrm{HCl}\right)$ in a microwave oven (CEM Mars 5, CEMS, Matthews, NC, USA) and were filtered before chemical analysis. The concentrations of $\mathrm{Cd}, \mathrm{Ni}$, and $\mathrm{Pb}$ were determined by inductively coupled plasma mass spectrometry (ICP-MS; Varian 820-MS, Varian Inc., Victoria, Australia). The overall error that was associated with the analytical process was usually lower than $6 \%$ and was never higher than $10 \%$.

\subsection{Data Analysis}

To evaluate the overall degree of contamination at each SS, we calculated the Potential Ecological Risk Index (PERI) proposed by Hakanson [31] and adapted it to the study region and to the elements that were considered.

For the calculation of the PERI values, the Toxic-response Factor (TrF) for each element and the Contamination Factor (CF) had to first be determined. To calculate the $\operatorname{TrF}$ (see Table 2), we estimated the "abundance number" of each element and the "sink-factor" of $\mathrm{Cd}$ and $\mathrm{Pb}$ from the raw 
data given by Hakanson [31]. The "sink-factor" of Ni was estimated from the background values that were reported by Carral [32] for sediments in the Galician Rias (NW Spain), as preindustrial values of $\mathrm{Ni}$ in sediments were not included in the original study. The CF values were obtained by dividing the concentration of each metal at each SS by the background values that were reported by Carballeira et al. [33] for the region. The potential ecological risk factors for each element in each SS were then calculated as $\operatorname{TrF} \times \mathrm{CF}$ (see Table 3). Finally, the PERI values were calculated for each SS as the sum of the risk factors.

Table 2. Results of the calculation of the "abundance number", "sink-factor", and Toxic-response Factor for each element.

\begin{tabular}{cccc}
\hline Metal & “Abundance Number" & “Sink-Factor" & $\operatorname{TrF}$ \\
\hline $\mathrm{Ni}$ & 1 & 320 & 1 \\
$\mathrm{~Pb}$ & 2.1 & 350 & 1.5 \\
$\mathrm{Cd}$ & 77.9 & 80 & 4.4 \\
\hline
\end{tabular}

Table 3. Results of the calculation of the Contamination Factor (CF) and the Risk Factor of each element in each sampling site.

\begin{tabular}{ccccccc}
\hline \multirow{2}{*}{ SS } & \multicolumn{2}{c}{ Cd } & \multicolumn{2}{c}{ Ni } & \multicolumn{2}{c}{ Pb } \\
\cline { 2 - 7 } & CF & Risk Factor & CF & Risk Factor & CF & Risk Factor \\
\hline A 1 & 7.50 & 33 & 8.33 & 0.6 & 16.36 & 25 \\
A 2 & 7.50 & 33 & 11.67 & 0.9 & 10.91 & 16 \\
A 3 & 2.50 & 11 & 7.00 & 0.5 & 4.05 & 6 \\
B 1 & 3.75 & 17 & 10.00 & 0.7 & 3.23 & 5 \\
B 2 & 1.25 & 6 & 7.67 & 0.6 & 1.09 & 2 \\
C 1 & 3.75 & 17 & 16.67 & 1.2 & 1.91 & 3 \\
C 2 & 2.50 & 11 & 10.83 & 0.8 & 1.32 & 2 \\
C 3 & 1.25 & 6 & 12.50 & 0.9 & 1.50 & 2 \\
D 1 & 1.25 & 6 & 5.83 & 0.4 & 1.32 & 2 \\
D 2 & 1.25 & 6 & 3.75 & 0.3 & 0.45 & 1 \\
E 1 & 1.25 & 6 & 6.75 & 0.5 & 0.86 & 1 \\
E 2 & 1.25 & 6 & 10.00 & 0.7 & 2.14 & 3 \\
\hline
\end{tabular}

The Shapiro-Wilk test was used to test the normality of each data set prior to the statistical analysis. As most of the variables were not normally distributed and Box-Cox transformation was not possible, a non-parametric Spearman's correlation test was used to establish any relationship between the variables: glutathione concentration-PERI and glutathione concentration-metal concentration. All of the tests were carried out using the statistical package IBM SPSS, version 20.0 (IBM, New York, NY, USA).

\section{Results and Discussion}

Chelation of metals in the cytosol by high-affinity ligands is a potentially important mechanism of heavy metal detoxification and tolerance in plants [34]. Although cysteine-rich heavy metal-binding peptides, metallothioneins, organic acids, amino acids, and glutathione can carry out this function, in most eukaryotes it is generally carried out by PCs. However, in bryophytes it appears that the function is mainly carried out by glutathione $[10,25,26,28]$. Thus, mosses living in environments that are characterised by high levels of metals are expected to have higher concentrations of glutathione than mosses living in areas characterised by low levels of metals. This was confirmed in the present study by the following findings (Figure 1A,B1): (i) the glutathione concentrations were higher in the mosses from the SS that was closest to the factories than in the mosses from the SS that was farthest from the factories when PERI > 21, indicating the occurrence of a toxicity threshold; and (ii) the glutathione concentration was significantly correlated with the PERI values (Spearman rho $=0.67 ; p<0.05$ ). 



Figure 1. (A) Logarithm of the total glutathione concentration $\left(\mu \mathrm{g} \mathrm{g}{ }^{-1}\right.$ f.w.; vertical lines show the standard deviation), Metal Contamination Factor for $\mathrm{Cd}, \mathrm{Pb}$, and $\mathrm{Ni}$ and the PERI (line and values in red) in the moss tissues in each sampling site ( $\mathrm{A}$ and $\mathrm{B}=$ ferrous smelter, $\mathrm{C}=$ aluminium smelter, $\mathrm{D}=$ ceramics factory, $\mathrm{E}=$ chipboard manufacturing plant). (B) Spearman correlations ( $p$ ) between the total glutathione concentration ( $\mu \mathrm{g} \mathrm{g}^{-1}$ f.w.) and PERI (1), Cd concentration ( $\mu \mathrm{g} \mathrm{g}^{-1} \mathrm{~d}$.w.) (2), Pb concentration ( $\mu \mathrm{g} \mathrm{g}^{-1} \mathrm{~d}$.w.) (3), and Ni concentration ( $\mu \mathrm{g} \mathrm{g}^{-1}$ d.w.) (4) in mosses. n.s. = not significant.

The glutathione threshold response could explain why moss can bioaccumulate high concentrations of pollutants without being damaged. In fact, glutathione could increase when a certain level of metals is reached in the cells, thereby decreasing the potential toxicity of the metals and enabling the cells to accumulate more contaminants. By contrast, when the value of PERI does not 
exceed 21, i.e., in SS with low levels of metal pollution, glutathione concentrations remain constant at a concentration equivalent to $40 \mu \mathrm{g} \mathrm{g}^{-1}$ (SS D1, D2, E1, and E2; Figure 1A), and could be involved in other cellular functions (e.g., synthesis, redox turnover, metabolism, and signalling), as suggested by Noctor et al. [19]. This threshold is not unique for all moss species, and it is worth noting that glutathione concentration in moss that is grown in controlled conditions is very variable depending on the species, and an increase of glutathione was already observed in three out of four species of moss that were exposed to Cd [28].

One possible explanation for this finding is the presence of other atmospheric pollutants in some of the SS. For practical reasons, the calculation of the PERI cannot take into account all toxic substances, and those elements/compounds of particular interest must be selected for this purpose. For example, Hakanson [31] only considered $\mathrm{Hg}, \mathrm{Cd}, \mathrm{As}, \mathrm{Cu}, \mathrm{Pb}, \mathrm{Cr}, \mathrm{Zn}$, and PCBs. Of the three elements that were considered in this study, $\mathrm{Cd}$ is the most toxic $[35,36]$ and therefore, the risk factor for $\mathrm{Cd}$ may explain about $70 \%$ of the PERI values for most of the SS and may also explain why this is the only metal that is significantly correlated with the glutathione concentration (Spearman rho $=0.65, p<0.05$; Figure 1B2-B4). Thus, the glutathione response in B1 may be due to element(s) other than those used in this study to calculate PERI and the fact that these elements were not present in equal amounts in C1.

On the other hand, the concentrations of elements in moss cannot be studied by only considering the total concentrations of pollutants in the tissues. Pollutants may be located in different cell compartments (intercellular, extracellular, intracellular, and particulate), which will respond differently from and independently of the presence of contaminants $[37,38]$. The concentrations in each compartment will be determined by the nature of the pollutant (each source of pollution may emit the metals in different chemical forms and the metals may be linked or not to different particles), as well as by the biological processes that occur within the moss and by environmental conditions [39]. Thus, the bioavailability of metal to moss will differ depending on its location in the cell. Unfortunately, it is not yet possible to determine only the fraction that is bioavailable to moss [8,9]. Therefore, the levels of concentrations of bioavailable $\mathrm{Cd}$ may be different in factories $\mathrm{B}$ and $\mathrm{C}$. Thus, the influence of the metal bioavailability on the glutathione concentration must be taken into account to avoid underestimating the pollution levels in the study area.

\section{Conclusions}

Glutathione plays an important role in the capacity of moss to bioaccumulate large amounts of pollutants. The action of this compound as a heavy metal chelator is essential to prevent moss from suffering the toxic effects of heavy metals. This function is demonstrated in the present study by the existence of a glutathione threshold response in samples of terrestrial mosses that were obtained from industrial environments that were characterised by high atmospheric levels of $\mathrm{Cd}, \mathrm{Ni}$, and $\mathrm{Pb}$. Although other toxic environments (with PERI values between 50 and 21) should be studied, the results suggest that glutathione could be used as a biomarker in air pollution biomonitoring studies with P. purum via the measurement of total glutathione concentrations, always taking into account the influence of metal bioavailability on these concentrations.

Author Contributions: Conceptualization, Z.V., D.K.S., J.R.A. and J.Á.F.; Formal analysis, Z.V. and S.D.; Funding acquisition, J.R.A. and J.Á.F.; Investigation, Z.V., S.D., J.R.A. and J.Á.F.; Methodology, J.R.A. and J.Á.F.; Resources, J.R.A. and J.Á.F.; Validation, Z.V.; Visualization, Z.V.; Writing—original draft, Z.V. and S.D.; Writing一review \& editing, Z.V., D.K.S., J.R.A. and J.Á.F.

Funding: The authors of the Ecology Unit belong to the Galician Competitive Research Group GRC/GPC2016-002 and to the CRETUS Strategic Partnership (AGRUP2015/02). All of these programmes are co-funded by FEDER (EU).

Conflicts of Interest: The authors declare that there are no conflicts of interest regarding the publication of this paper. 


\section{References}

1. Varela, Z.; Aboal, J.R.; Carballeira, A.; Real, C.; Fernández, J.A. Use of a moss biomonitoring method to compile emission inventories for small-scale industries. J. Hazard. Mater. 2014, 275, 72-78. [CrossRef] [PubMed]

2. Fernández, J.A.; Boquete, M.T.; Carballeira, A.; Aboal, J.R. A critical review of protocols for moss biomonitoring of atmospheric deposition: Sampling and sample preparation. Sci. Total Environ. 2015, 517, 132-150. [CrossRef] [PubMed]

3. Aboal, J.R.; Fernández, J.A.; Boquete, T.; Carballeira, A. Is it possible to estimate atmospheric deposition of heavy metals by analysis of terrestrial mosses? Sci. Total Environ. 2010, 408, 6291-6297. [CrossRef] [PubMed]

4. Boquete, M.T.; Fernández, J.A.; Carballeira, A.; Aboal, J.R. Relationship between trace metal concentrations in the terrestrial moss Pseudoscleropodium purum and in bulk deposition. Environ. Pollut. 2015, 201, 1-9. [CrossRef] [PubMed]

5. Couto, J.A.; Aboal, J.R.; Fern_andez, J.A.; Carballeira, A. A new method for testing the sensitivity of active biomonitoring: An example of its application to a terrestrial moss. Chemosphere 2004, 57, 303-308. [CrossRef] [PubMed]

6. Carballeira, C.B.; Aboal, J.R.; Fernández, J.A.; Carballeira, A. Comparison of the accumulation of elements in two terrestrial moss species. Atmos. Environ. 2008, 42, 4904-4917. [CrossRef]

7. González, A.G.; Pokrovsky, O.S. Metal adsorption on mosses: Toward a universal adsorption model. J. Colloid Interface Sci. 2014, 415, 169-178. [CrossRef] [PubMed]

8. Pérez-Llamazares, A.; Ángel Fernández, J.; Carballeira, A.; Aboal, J.R. The sequential elution technique applied to cryptogams: A literature review. J. Bryol. 2011, 33, 267-278. [CrossRef]

9. Spagnuolo, V.; Giordano, S.; Adamo, P.; Pérez-Llamazares, A.A.; Carballeira, A.; Fernández, J.A.; Aboal, J.R. Distinguishing metal bioconcentration from PM in moss tissue: Testing methods of removing particles attached to the moss surface. Sci. Total Environ. 2013, 463, 727-733. [CrossRef] [PubMed]

10. Bruns, I.; Sutter, K.; Menge, S.; Neumann, D.; Krauss, G.J. Cadmium lets increase the Glutathione pool in bryophytes. J. Plant Physiol. 2001, 158, 79-89. [CrossRef]

11. Takács, Z.; Tuba, Z.; Smirnoff, N. Exaggeration of desiccation stress by heavy metal pollution in Tortula ruralis: A pilot study. Plant Growth Regul. 2001, 35, 157-160. [CrossRef]

12. Saxena, A.; Saxena, A. Bioaccumulation and Glutathione-mediated detoxification of copper and cadmium in Sphagnum squarrosum Crome Samml. Environ. Monit. Assess. 2012, 184, 4097-4103. [CrossRef] [PubMed]

13. Rauser, W.E. Structure and function of metal chelators produced by plants. Cell Biochem. Biophys. 1999, 31, 19-48. [CrossRef] [PubMed]

14. Meyer, A.J.; Hell, R. Glutathione homeostasis and redox-regulation by sulfhydryl groups. Photosynth. Res. 2005, 86, 435-457. [CrossRef] [PubMed]

15. Hussain, I.; Iqbal, M.; Qurat-Ul-Ain, S.O.B.I.A.; Rasheed, R.; Mahmood, S.; Perveen, A.; Wahid, A. Cadmium dose and exposure-time dependent alterations in growth and physiology of maize (Zea mays). Int. J. Agric. Biol. 2012, 14, 959-964.

16. Hernández, L.E.; Sobrino-Plata, J.; Montero-Palmero, M.B.; Carrasco-Gil, S.; Flores-Cáceres, M.L.; Ortega-Villasante, C.; Escobar, C. Contribution of glutathione to the control of cellular redox homeostasis under toxic metal and metalloid stress. J. Exp. Bot. 2015, 66, 2901-2911. [CrossRef] [PubMed]

17. Huang, G.Y.; Wang, Y.S.; Sun, C.C.; Dong, J.D.; Sun, Z.X. The effect of multiple heavy metals on ascorbate, glutathione and related enzymes in two mangrove plant seedlings (Kandelia candel and Bruguiera gymnorrhiza). Oceanol. Hydrobiol. Stud. J. 2010, 39, 11-25. [CrossRef]

18. Rausch, T.; Gromes, R.; Liedschulte, V.; Müller, I.; Bogs, J.; Galovic, V.; Wachter, A. Novel insight into the regulation of GSH biosynthesis in higher plants. Plant Biol. 2007, 9, 565-572. [CrossRef] [PubMed]

19. Noctor, G.; Mhamdi, A.; Chaouch, S.; Han, Y.I.; Neukermans, J.; Marquez-Garcia, B.; Queval, G.; Foyer, C.H. Glutathione in plants: An integrated overview. Plant Cell Environ. 2012, 35, 454-484. [CrossRef] [PubMed]

20. Hernández-allica, J.; Garbisu, C.; Becerril, J.M.; Barrutia, O.; García-plazaola, J.I.; Zhao, F.J.; McGrath, S.P. Synthesis of low molecular weight thiols in response to Cd exposure in Thlaspi caerulescens. Plant Cell Environ. 2006, 29, 1422-1429. [CrossRef] [PubMed]

21. Gupta, D.K.; Huang, H.G.; Yang, X.E.; Razafindrabe, B.H.N.; Inouhe, M. The detoxification of lead in Sedum alfredii $\mathrm{H}$. is not related to phytochelatins but the glutathione. J. Hazard. Mater. 2010, 177, 437-444. 
22. Schat, H.; Llugany, M.; Vooijs, R.; Hartley-Whitaker, J.; Bleeker, P.M. The role of phytochelatins in constitutive and adaptive heavy metal tolerances in hyperaccumulator and non-hyperaccumulator metallophytes. J. Exp. Bot. 2002, 53, 2381-2392. [CrossRef] [PubMed]

23. Noctor, G.; Arisi, A.C.M.; Jouanin, L.; Foyer, C.H. Manipulation of glutathione and amino acid biosynthesis in the chloroplast. Plant Physiol. 1998, 118, 471-482. [CrossRef] [PubMed]

24. Schaefer, H.J.; Greiner, S.; Rausch, T.; Haag-Kerwer, A. In seedlings of the heavy metal accumulator Brassica juncea $\mathrm{Cu}^{2+}$ differentially affects transcript amounts for gamma-glutamylcysteine synthetase (gamma-ECS) and metallothionein (MT2). FEBS Lett. 1997, 404, 216-220. [CrossRef]

25. Bleuel, C.; Wesenbetg, D.; Sutter, K.; Miersch, J.; Braha, B.; Bärlocher, F.; Krauss, G.J. The use of the aquatic moss Fontinalis antipyretica L. ex Hedw. as a bioindicator for heavy metals: 3. $\mathrm{Cd}^{2+}$ accumulation capacities and biochemical stress response of two Fontinalis species. Sci. Total Environ. 2005, 345, 13-21. [CrossRef] [PubMed]

26. Leinenweber, G.; Stegen, S.; Diaz-Palma, P. Increase of total glutathione as a response to Cd induced stress in a Chilean endemic bryophytes (Thuidium sp.). J. Chil. Chem. Soc. 2009, 54, 401-404. [CrossRef]

27. Saxena, A.; Saxena, D.K.; Srivastava, H.S. The influence of Glutathione on physiological effects of lead and its accumulation in moss Sphagnum squarrosum. Water Air Soil Pollut. 2003, 143, 351-361. [CrossRef]

28. Petraglia, A.; De Benedictis, M.; Degola, F.; Pastore, G.; Calcagnho, M.; Ruotolo, R.; Mengoni, A.; di Toppi, L.S. The capability to synthesize phytochelatins and the presence of constitutive and functional phytochelatin synthases are ancestral (plesiomorphic) characters for basal land plants. J. Exp. Bot. 2014, 65, 1153-1163. [CrossRef] [PubMed]

29. Fernández, J.A.; Aboal, J.R.; Real, C.; Carballeira, A. A new method biomonitoring method for detecting sources of small scale pollution. Atmos. Environ. 2007, 41, 2098-2110. [CrossRef]

30. Fernandez, J.A.; Aboal, J.R.; Couto, J.A.; Carballeira, A. Sampling optimization at the sampling-site scale for monitoring atmospheric deposition using moss chemistry. Atmos Environ. 2002, 36, 1163-1172. [CrossRef]

31. Hakanson, L. An ecological risk index for aquatic pollution control. A sedimentological approach. Water Res. 1980, 14, 975-1001. [CrossRef]

32. Carral, E.; Puente, X.; Villares, R.; Carballeira, A. Background heavy metal levels in estuarine sediments and organisms in Galicia (northwest Spain) as determined by modal analysis. Sci. Total Environ. 1995, 172, 175-188. [CrossRef]

33. Carballeira, A.; Couto, J.A.; Fernández, J.A. Estimation of background levels of various elements in terrestrial mosses from Galicia (NW Spain). Water Air Soil Pollut. 2002, 133, 235-252. [CrossRef]

34. Hall, J.L. Cellular mechanisms for heavy metal detoxification and tolerance. J. Exp. Bot. 2002, 53, 1-11. [CrossRef] [PubMed]

35. Das, P.; Samantaray, S.; Rout, G.R. Studies on cadmium toxicity in plants: A review. Environ. Pollut. 1997, 98, 29-36. [CrossRef]

36. Vig, K.; Megharaj, M.; Sethunathan, N.; Naidu, R. Bioavailability and toxicity of cadmium to microorganisms and their activities in soil: A review. Adv. Environ. Res. 2003, 8, 121-135. [CrossRef]

37. Brown, D.H.; Wells, J.M. Sequential Elution Technique for Determining the Cellular Location of Cations. In Methods in Bryology; Glime, J.M., Ed.; Hattori Botanical Laboratory: Nichinan, Japan, 1988; pp. 227-233.

38. Brown, D.H. Sequential Elution Procedures for Establishing the Cellular Distribution Patterns of Metals in Cryptogamic Plants. In Bioindicators of Environmental Health; Munawar, M., Hänninen, O., Roy, S., Munawar, N., Kärenlampi, L., Brown, D., Eds.; SPB Academic Publishing: Amsterdam, The Netherlands, 1995; pp. 203-209.

39. Fernández, J.Á.; Pérez-Llamazares, A.; Carballeira, A.; Aboal, J.R. Temporal variability of metal uptake in different cell compartments in mosses. Water Air Soil Pollut. 2013, 224, 1481. [CrossRef]

(C) 2018 by the authors. Licensee MDPI, Basel, Switzerland. This article is an open access article distributed under the terms and conditions of the Creative Commons Attribution (CC BY) license (http:/ / creativecommons.org/licenses/by/4.0/). 